\title{
Intermedin in rat uterus: changes in gene expression and peptide levels across the estrous cycle and its effects on uterine contraction
}

\author{
Chi-Wai Wong ${ }^{1}$, Wai-Sum $\mathrm{O}^{2,3}$ and Fai Tang ${ }^{1,4^{*}}$
}

\begin{abstract}
Background: The present study demonstrates the expression of intermedin (IMD) and its receptor components in the uterus of the female rat during the estrous cycle and its effect on uterine contraction.

Methods: The gene expression level of intermedin and its receptor components and the peptide level of intermedin were studied by real-time RT-PCR and enzyme immunoassay (EIA) respectively. The separation of precursor and mature IMD was studied by gel filtration chromatography and EIA. The localization of IMD in the uterus was investigated by immunohistochemistry. The effect of IMD on in vitro uterine contraction was studied by organ bath technique.

Results: Uterine mRNAs of Imd and its receptor components and IMD levels displayed cyclic changes across the estrous cycle. Imd mRNA level was the highest at proestrus while the IMD level was the highest at diestrus. IMD was found in the luminal and glandular epithelia and IMD treatment significantly reduced the amplitude and frequency of uterine contraction but not the basal tone. Both calcitonin gene-related peptide (CGRP) receptor antagonist hCGRP837 and adrenomedullin (ADM) receptor antagonist hADM22-52 partially abolished the inhibitory effect of IMD on uterine contraction while the specific IMD receptor antagonist hIMD17-47 completely blocked the actions. The enzyme inhibitors of NO (L-NAME) and PI3K (Wortmannin) pathways diminished the IMD effects on uterine contraction while the cAMP/PKA blocker, KT5720, had no effect, indicating an involvement of NO and PI3K/Akt but not PKA.

Conclusions: IMD and the gene expression of its receptor components are differentially regulated in the uterus during the estrous cycle and IMD inhibits uterine contraction by decreasing the amplitude and frequency.
\end{abstract}

Keywords: Intermedin, Estrous cycle, Uterine contraction

\section{Background}

Intermedin (IMD), calcitonin, calcitonin gene-related peptide (CGRP), adrenomedullin (ADM), and amylin, all belong to the calcitonin/calcitonin gene-related peptide family [1-7]. IMD (also known as adrenomedullin 2 or ADM2), evolved early in vertebrates, is a 47 -amino-acid peptide sharing about $28 \%$ and $<20 \%$ homology with ADM and CGRP respectively in the middle region of the peptides [2,3]. Similar to ADM, IMD signals through

\footnotetext{
* Correspondence: ftang@hkucc.hku.hk

'Departments of Physiology, Li Ka Shing Faculty of Medicine, The University of Hong Kong, Pokfulam, Hong Kong SAR, China

${ }^{4}$ Center of Heart, Brain, Hormone and Healthy Aging, Li Ka Shing Faculty of Medicine, The University of Hong Kong, Pokfulam, Hong Kong SAR, China Full list of author information is available at the end of the article
}

the calcitonin receptor-like receptor (CRLR)/receptor activity-modifying proteins (RAMPs) receptor complexes [1-3]. However, ADM shows a preferential stimulation of receptors formed by the coexpression of CRLR with RAMP2 or RAMP3, whereas IMD is a nonselective agonist for all these receptors [1-3].

Produced from the prointermedin molecule are three molecular species of IMD which are biologically active i.e. $\mathrm{IMD}_{1-53}, \mathrm{IMD}_{1-47}$ and $\mathrm{IMD}_{8-47}[7]$. IMD has several functions similar to those of ADM. Both IMD and ADM are potent vasodilators $[2,8,9]$ and are anorexogenic $[2,4,10]$. Both suppress stomach emptying $[2,11,12]$ and increase circulating prolactin levels $[2,13,14]$. However, IMD also has its own effects not shared by ADM [15-21]. The effects of IMD on the cardiovascular

\section{Biomed Central}


Table 1 Gene primer sequences and GenBank accession number of rat for the real-time PCR

\begin{tabular}{|c|c|c|c|}
\hline Genes & Primer Sequences & GenBank Accession Number & Product Size (bp) \\
\hline \multirow[t]{2}{*}{ Imd } & F: $\mathbf{5}^{\prime}$-GCTGATGGTCACGGTAAC-3' & NM_201426.1 & 122 \\
\hline & R: $\mathbf{5}^{\prime}-C G C T G G A A G G A A T C T T G G-3^{\prime}$ & & \\
\hline \multirow[t]{2}{*}{ Crlr } & F: $\mathbf{5}^{\prime}$-CCAAACAGACTTGGGAGTCACTAGG-3' & NM_012717.1 & 323 \\
\hline & R: 5'- GCTGTCTTCTCTITCTCATGCGTGC-3' & & \\
\hline \multirow[t]{2}{*}{ Ramp1 } & F: $\mathbf{5}^{\prime}-$ CACTCACTGCACCAAACTCGTG-3' & NM_031645.1 & 196 \\
\hline & R: $\mathbf{5}^{\prime}$ - CAGTCATGAGCAGTGTGACCGTAA-3' & & \\
\hline \multirow[t]{2}{*}{ Ramp2 } & F: $\mathbf{5}^{\prime}$ - AGGTATTACAGCAACCTGCGGT-3' & NM_031646.1 & 163 \\
\hline & R: 5'- ACATCCTCTGGGGGATCGGAGA-3' & & \\
\hline \multirow[t]{2}{*}{ Ramp3 } & F: 5'- ACCTGTCGGAGTTCATCGTG-3' & NM_020100.2 & 180 \\
\hline & R: 5' - ACTTCATCCGGGGGGTCTTC-3' & & \\
\hline \multirow[t]{2}{*}{ Actb } & F: 5'- GGAAATCGTGCGTGACATTA-3' & NM_031144.2 & 183 \\
\hline & R: $\mathbf{5}^{\prime}-$ AGGAAGGAAGGCTGGAAGAG-3' & & \\
\hline
\end{tabular}

system have been extensively investigated [7,16-18,21] whereas the study of IMD in reproduction has been confined to oocyte regulation [22], trophoblast invasion and migration [15,19], and embryonic development [20].

Both uterine ADM expression [23,24] and the response of uterine contraction to ADM $[25,26]$ have been investigated. Uterine endometrium has been shown to have more ADM than the myometrium in rats [23], and in humans [27]. Rat uterine endometrial ADM expression peaks at proestrus and estrus and is regulated by estrogen [23,24].

Our laboratory has previously investigated the expression and functions of ADM in the reproductive system [28-38]. In the female rat, the gene expression and peptide levels of

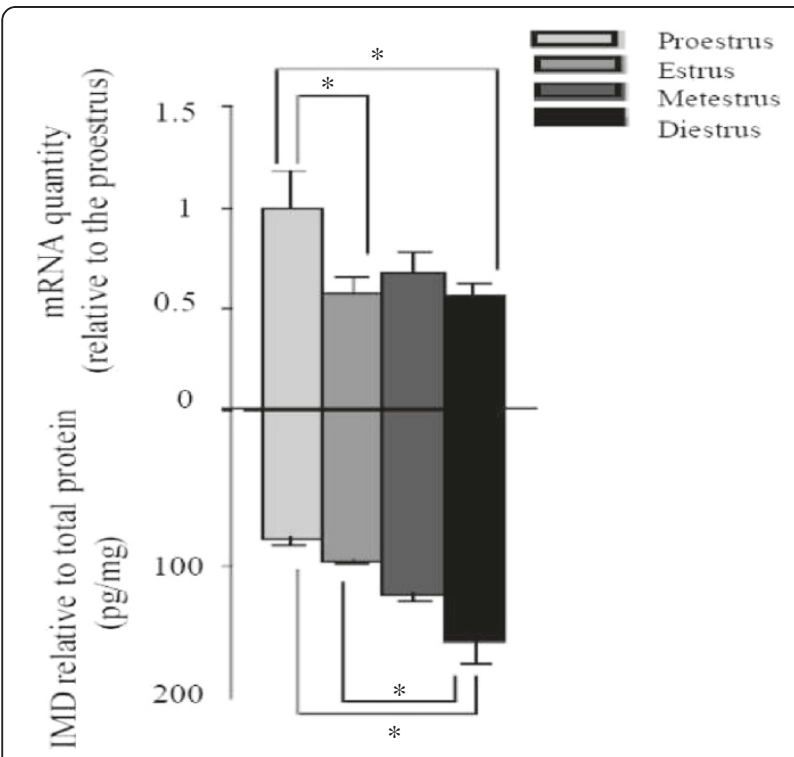

Figure 1 Imd mRNA and IMD levels in the uterus across estrous cycle. $n=6,6,7$, and 9 for the four stages respectively. The mRNA levels were normalized to Actb mRNAs, and each value represents the mean \pm SEM. ${ }^{*} \mathrm{P}<0.01$.
ADM change during the estrous cycle [33]. ADM inhibits ovarian steroidogenesis [33], stimulates ciliary beating but inhibits muscle contraction in the oviduct [35], and plays important roles in pregnancy $[34,36]$. As ADM is known to inhibit uterine contraction $[25,26]$, we have investigated the changes of IMD gene expression and peptide levels in the uterus during the estrous cycle and its effect on spontaneous uterine contraction to understand the possible roles of IMD in the uterus.

\section{Methods \\ Animals}

Female Sprague-Dawley (SD) rats (12-13 wk) were obtained from the Laboratory Animal Unit, LKS Faculty of Medicine, the University of Hong Kong. The rats were housed at a constant temperature and humidity, under a 12-h light-dark cycle (dark period 07:00h to 19:00h), with water and rat chow ad libitum. Vaginal smears were obtained daily from 36 rats, and 28 rats that showed a regular 4-day estrous cycle were included in this study. Staging of the cycle into estrus and diestrus was based on the cytology of the vaginal smear. All rats were killed between 10:00 a.m. and 12:00 noon and the uteri were collected and snap-frozen in liquid nitrogen for storage at $-80^{\circ} \mathrm{C}$ until further analysis. Immature rats injected with gonadotropin were used for the contraction study (please see a later section). All procedures had been approved by the Committee on the Use of Live Animals for Teaching and Research, the University of Hong Kong.

\section{RT-PCR of Imd, CrIr, and Ramps}

Total RNA of the uterus was obtained by homogenization in TRIZOL reagent (Life Technologies, Carlsbad, CA, USA) using a polytron (Kinematica, Switzerland) [34] and subjected to RT-PCR. RNA samples $(5 \mu \mathrm{g})$ were reverse transcribed into complementary DNA (cDNA) with the 


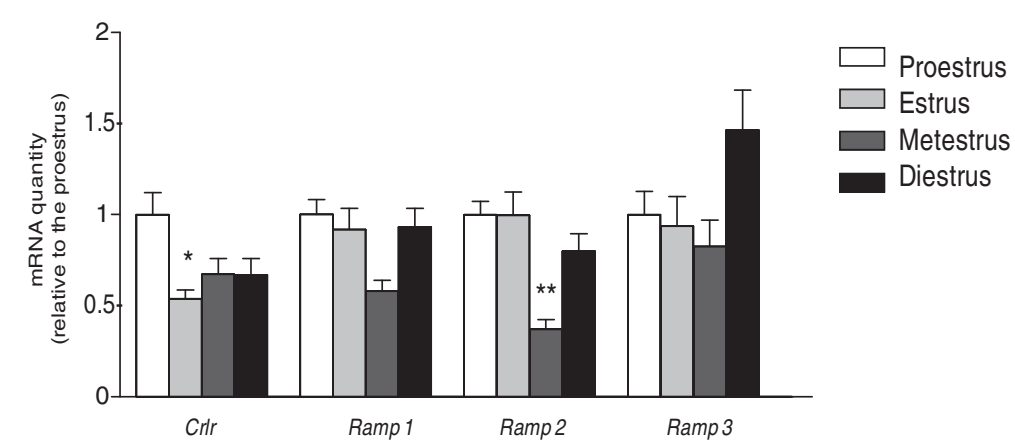

Figure 2 Expression of uterine CrIr, Ramp1, Ramp2, and Ramp3 mRNAs across estrous cycle. $n=6,6,7$, and 9 for the four stages respectively, ${ }^{*} P<0.05$ compared with the proestrus stage, ${ }^{* *} P<0.05$ compared with all the other stages,

SuperScript II reverse transcriptase (Life Technologies, Carlsbad, CA). The real time RT-PCR technique has been previously described [35]. Polymerase chain reactions (PCR) were conducted by an iCycler iQ real-time PCR detection system (Bio-Rad Laboratories, Hercules, CA, USA) using iQ SYBR Green Supermix (Bio-Rad Laboratories, Hercule, CA). Three house-keeping genes (ribosomal protein L19, $\beta$-actin, and $18 \mathrm{~S}$ ribosomal RNA) were tested and $\beta$-actin $(A c t b)$ was used as an internal standard based on its uniform expression across the groups. Standard curves for each primer pair were prepared by the serial dilution of cDNA to determine the PCR efficiency. The PCR efficiencies for Imd, Crlr, Ramp1, Ramp2, Ramp3 and Actb

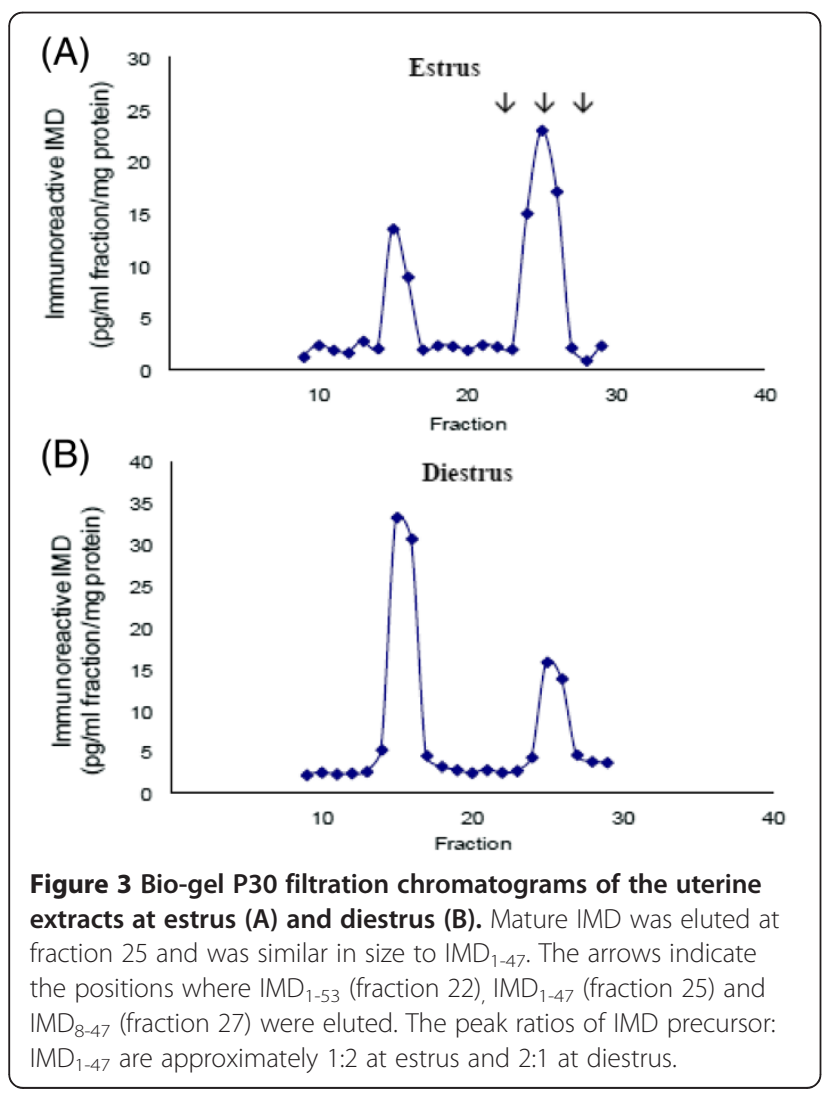

( $\beta$-actin used as an internal standard) were all above 0.95 . The relative gene expression levels were then analyzed by the $\Delta \Delta \mathrm{Ct}$ method [39], where $\mathrm{Ct}$ is the cycle threshold. The reaction mixtures contained $10 \mu \mathrm{l}$ iQ SYBR Green Supermix (Bio-Rad Laboratories, Hercules, CA, USA), $2 \mu \mathrm{l}$ template cDNA, $100 \mathrm{nM}$ of each primer, and DNase-free water (Life Technologies, Carlsbad, CA, USA) to a final volume of $20 \mu \mathrm{l}$. Cycle conditions were $95^{\circ} \mathrm{C}$ for $5 \mathrm{~min}$, followed by a maximum of 40 cycles of $95^{\circ} \mathrm{C}$ for $15 \mathrm{sec}$, $59^{\circ} \mathrm{C}$ for $15 \mathrm{sec}$, and $72^{\circ} \mathrm{C}$ for $15 \mathrm{sec}$, and extension at $72^{\circ} \mathrm{C}$ for 10 minutes. The reaction was completed with a dissociation step for melting point analysis with $50^{\circ} \mathrm{C}$ to $95^{\circ} \mathrm{C}$ (in increments of $0.5^{\circ} \mathrm{C}$ ) for $10 \mathrm{sec}$ each. The design of the primers was based on the published sequences (The details of the primers used and the sizes of the amplicons are shown in Table 1). Melt curve analysis for each primer showed only one peak for each product. The identities of all the PCR products were confirmed by gene sequencing (Tech Dragon Limited, Hong Kong).

\section{Measurement of IMD in the uterus}

Each tissue sample $(0.03 \mathrm{~g})$ was homogenized in $3 \mathrm{ml} 2 \mathrm{~N}$ acetic acid $(1 \mathrm{ml} / 0.01 \mathrm{~g}$ tissue, BDH Laboratory Supplies, Poole, England) and then boiled for $10 \mathrm{~min}$. A 50- $\mu \mathrm{l}$ aliquot was taken for the protein assay and the remaining homogenate was centrifuged at $18600 \mathrm{X} \mathrm{g}$ for $20 \mathrm{~min}$ at $4^{\circ} \mathrm{C}$ (Sorvall SM 24; Thermo Fisher Scientific, Inc., Waltham, MA). The supernatants were all lyophilized and stored at $-20^{\circ} \mathrm{C}$ until assay.

The lyophilized tissue samples were reconstituted in $1 \mathrm{X}$ IMD assay buffer. IMD level was measured with an IMD (1-50) (human) EIA kit (Phoenix Pharmaceuticals, Inc., Burlingame, CA, USA). The minimum detectable concentration was $0.26 \mathrm{ng} / \mathrm{ml}$ and the range was $0-100 \mathrm{ng} / \mathrm{ml}$. The intra-assay and inter-assay coefficients of variation were $<10 \%$ and $<15 \%$ respectively. The amount of protein in each sample was measured with a protein assay reagent (BioRad, Hercules, CA, USA) spectrophotometrically at 595 nm (LKB Ultraspec II; Biochem, Berlin, Germany). The immunoreactive IMD was expressed as $\mathrm{pg} / \mathrm{mg}$ protein. 

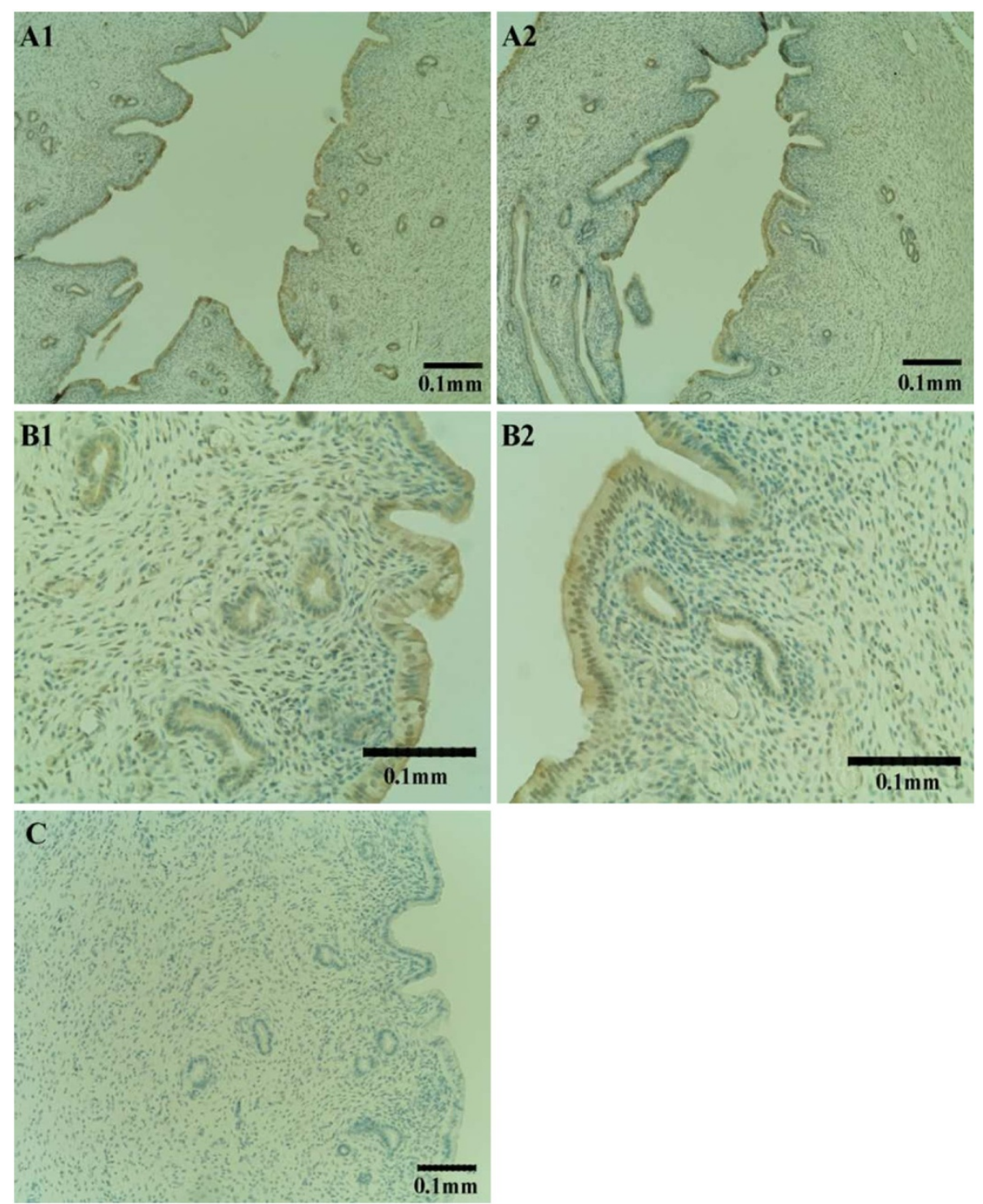

Figure 4 Immunohistochemical study of IMD in the uterus. Positive immunostaining at the luminal epithelium (A) and glandular epithelium (B) at both estrus (1) and diestrus (2); negative control without primary antibody (C).

\section{Gel filtration chromatography of the uterus}

The tissues were extracted with a polytron in $1 \mathrm{~N}$ acetic acid (BHD Laboratory Supplies, Poole, England) on ice (see above). A 50- $\mu$ l aliquot of the homogenate was stored at $-20^{\circ} \mathrm{C}$ until protein assay. The lyophilized tissue samples were reconstituted in Milli-Q water and centrifuged at $13000 \mathrm{rpm}$ for $20 \mathrm{~min}$ at $4^{\circ} \mathrm{C}$. Glacial acetic acid (96\%) (Sigma, St. Louis, MO, USA) was added to the supernatant to a final concentration of $1 \mathrm{~N}$ acetic acid. The samples (in $500 \mu \mathrm{l}$ of $1 \mathrm{~N}$ acetic acid) were then loaded on a Bio-gel P30 (Bio-Rad, Hercules, CA, USA) column $(0.9 \times 60 \mathrm{~cm})$ and the column was eluted with $1 \mathrm{~N}$ acetic acid at a flow rate of $1 \mathrm{ml} / 10 \mathrm{~min}$ for a total of $400 \mathrm{~min}$. One-millilitre fractions were lyophilized and measured for IMD immunoreactivities as stated before. The level of immunoreactive IMD was expressed in terms of $\mathrm{pg} / \mathrm{ml}$ of fraction $/ \mathrm{mg}$ protein. Authentic $\mathrm{IMD}_{1-53}, \mathrm{IMD}_{1-47}$ and $\mathrm{IMD}_{8-47}$ (1 ng each, Phoenix Pharmaceuticals, Inc., Burlingame, CA, USA) were loaded on the same column as markers.

\section{Immunohistochemistry}

To localize IMD in the uterus, a Vectastain $A B C$ kit (Vector Laboratories, Burlingame, CA, USA) was used for the avidin-biotin histochemical staining procedure. The uterine tissues were fixed in neutral buffered formalin overnight. Paraffin-embedded sections of $5 \mu \mathrm{M}$ 

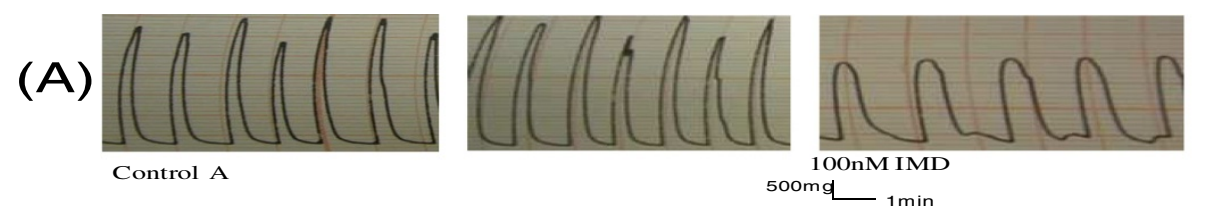

(B)

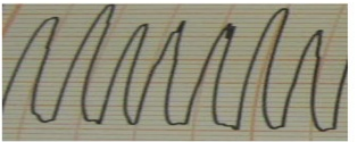

Control B
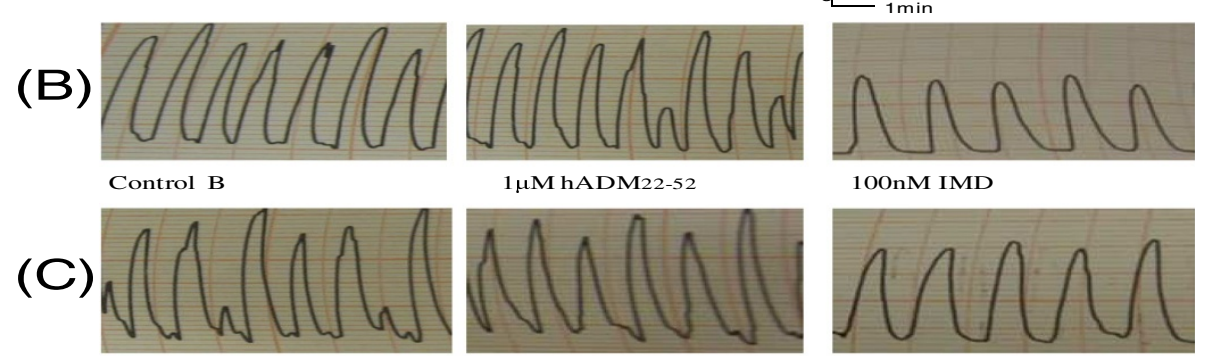

$1 \mu \mathrm{M}$ hADM22-52

10OnM IMD

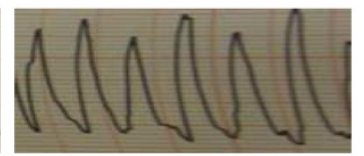

$1 \mu \mathrm{M}$ hCGRP8-37

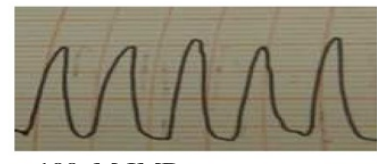

Control C

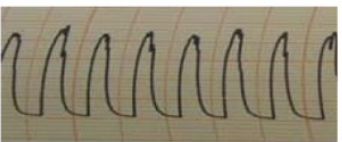

10OnM IMD

(D)

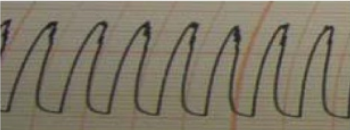

Control D

$1 \mu$ MIMD17-47

(E)

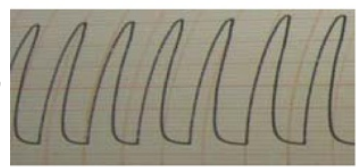

Control E

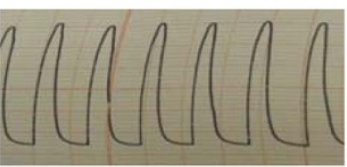

$1 \mu \mathrm{M}$ KT5720

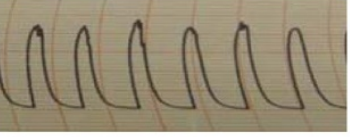

1OOnM IMD

(F)
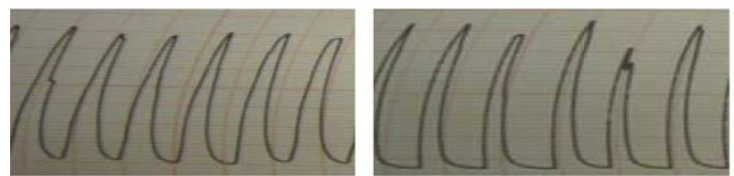

Control F

$100 \mu \mathrm{M}$ L-NAME

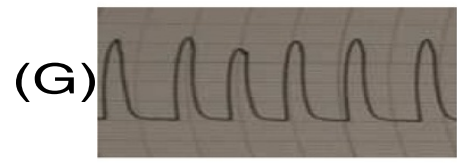

Control G

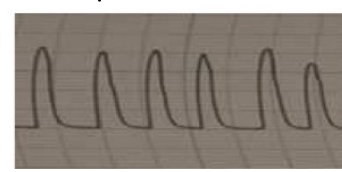

$1 \mu \mathrm{M}$ Wortmannin

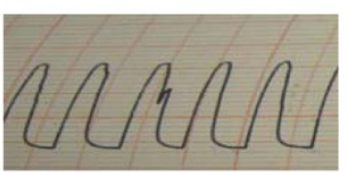

10OnM IMD

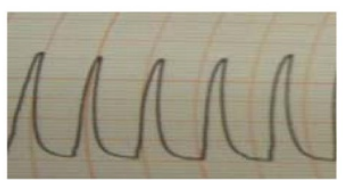

10OnM IMD

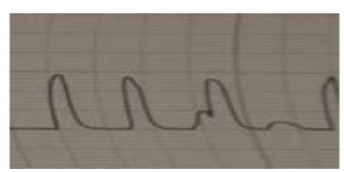

100nM IMD

Figure 5 Representative tracings of rat uterine muscular contraction in vitro. Treatment of IMD alone (A), and together with receptor blockers hADM 22-52 (B), hCGRP 8-37 $(\mathbf{C})$, or hIMD $17-47$ (D), or enzyme inhibitors of PKA (KT5720) (E), NO synthase (L-NAME) (F), or PI3K (Wortmannin)(G).

thickness were dewaxed, rehydrated and then treated with $3 \%$ hydrogen peroxide in phosphate buffer saline for $30 \mathrm{~min}$, followed by overnight incubation with 1:1000 diluted primary antibody of IMD (Phoenix Pharmaceuticals, Inc., Burlingame, CA, USA) at $4^{\circ} \mathrm{C}$. After washing, 1:200 biotinylated secondary antibody was added, followed by preformed $\mathrm{ABC}$ reagent (Rabbit ABC Staining System, Santa Cruz, U.S.A.). Diaminobenzidine was used to visualize the avidin-biotin-peroxidase complex for 5 to $10 \mathrm{~min}$.

\section{In vitro contraction experiment by an organ-bath technique}

Immature female SD rats (21-23 days) were treated with 30 IU pregnant mare's serum gonadotropin (PMSG)
$48 \mathrm{~h}$ prior to the collection of tissues to simulate the estrus stage (when the spontaneous contraction is the greatest). Uteri from the rats were isolated and rinsed in Kreb's solution $(115 \mathrm{mM} \mathrm{NaCl}, 4.7 \mathrm{mM} \mathrm{KCl}, 1 \mathrm{mM}$ $\mathrm{MgSO}_{4}, 15 \mathrm{mM} \mathrm{NaHCO} 3,1.2 \mathrm{mM} \mathrm{NaH} \mathrm{PO}_{4}, 10.5 \mathrm{mM}$ glucose, and $1.6 \mathrm{mM} \mathrm{CaCl}_{2}$ ) immediately [25,26,35]. The entire uterus [25] was then tied, via silk threads, to a tissue holder in a 10-ml organ bath containing Kreb's solution aerated with a mixture of oxygen and carbon dioxide (95:5\%) at a constant temperature of $37^{\circ} \mathrm{C}$. The tissue holder was attached to a force transducer coupled to a graph recorder. As a pilot study using 1, 10 and 100 nM IMD indicated that the uterine preparation only responded to $100 \mathrm{nM}$ IMD, the response to $100 \mathrm{nM}$ IMD (human IMD $\mathrm{I}_{1-53}$ ) was studied after 45-min equilibration. 

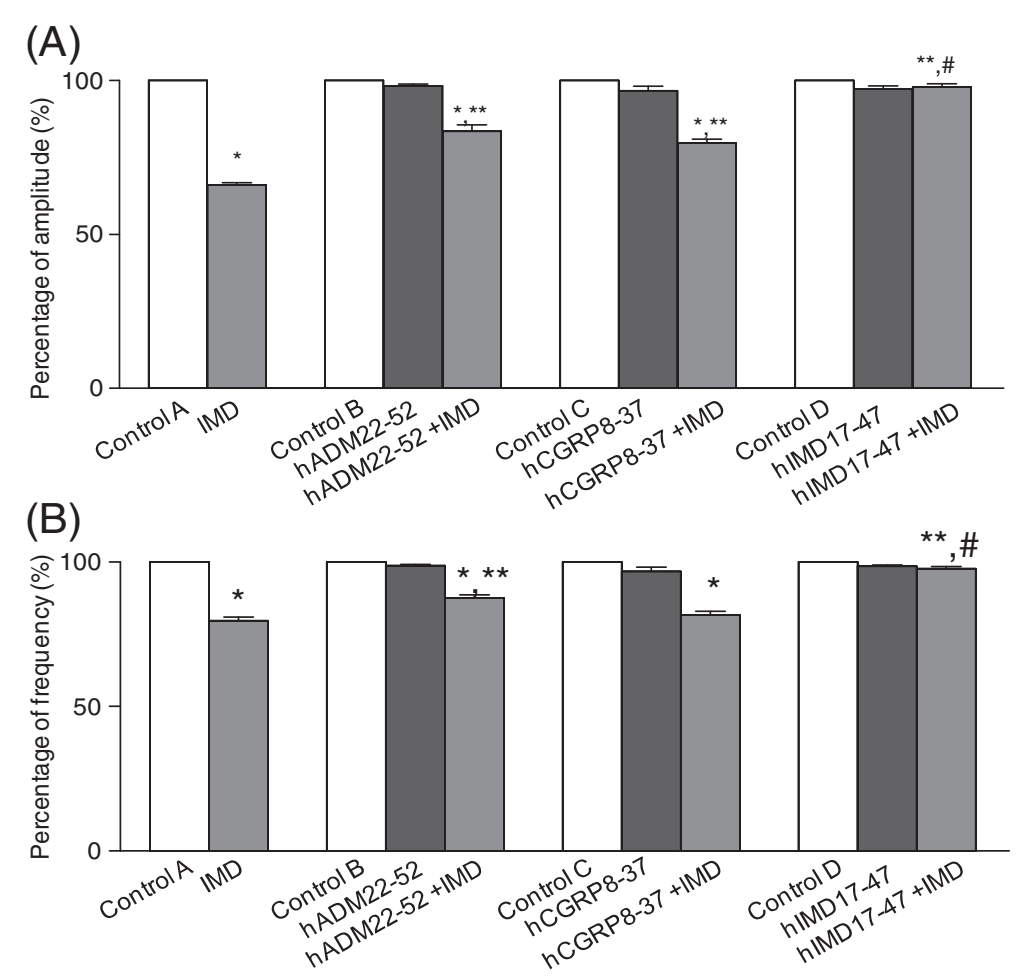

Figure 6 The effects of IMD receptor antagonists on the inhibition of uterine contraction by IMD. Decreased amplitude (A) and frequency (B) were observed after IMD treatment. Both $\mathrm{hADM}_{22-52}$ and hCGRP ${ }_{8-37}$ partially inhibited IMD actions. hIMD $_{17-47}$ completely blocked the relaxation effect of IMD on both the contraction amplitude $(\mathbf{A})$ and frequency $(\mathbf{B}) . \mathrm{n}=6$ for all treatments. Data are presented as mean \pm SEM. ${ }^{*} \mathrm{P}<0.01$ vs control or blocker alone, ** $\mathrm{P}<0.01$ vs IMD, $\# \mathrm{P}<0.01$ vs $\mathrm{hADM}_{22-52}+\mathrm{IMD}$ or hCGRP $8-37$ IMD.

For the study on receptor antagonism, the uteri were preincubated with $1 \mu \mathrm{M}$ hADM $22-52$ (ADM receptor antagonist), hCGRP ${ }_{8-37}$ (CGRP receptor antagonist), or $\mathrm{hIMD}_{17-47}$ (IMD receptor antagonist) or the vehicle for $1 \mathrm{~h}$, before the addition of $100 \mathrm{nM}$ IMD. For the signaling pathways, the uteri were preincubated with KT5720 $(1 \mu \mathrm{M}$, protein kinase A (PKA) inhibitor), N-nitro-L-arginine methyl ester (L-NAME) $(100 \mu \mathrm{M}$, nitric oxide (NO) synthase inhibitor), or Wortmannin $(1 \mu \mathrm{M}$, serinethreonine kinase/phosphoinositide 3-kinase (Akt/PI3K) inhibitor) (all from Sigma Chemicals, St. Louise, MO, USA.) before IMD (100 $\mathrm{nM})$ was added.

\section{Statistical analysis}

All the data were expressed as mean \pm standard error of the mean (SEM), and statistical significance was assessed by one-way analysis of variance (ANOVA) followed by Student-Newman-Keuls (SNK) test for post hoc comparisons, with $\mathrm{P}<0.05$ taken as significant.

\section{Results}

IMD immunoreactivity and mRNA level of Imd

The levels of IMD and Imd mRNA in the uterus of cycling rats were estimated by IMD EIA and real-time RT-
PCR respectively, and the results are shown in Figure 1. The Imd mRNA level at the proestrus stage was taken as 1 and it was higher than those at estrus and diestrus $(\mathrm{P}<0.01)$, with no difference between estrus and diestrus. The peptide level of IMD was higher at diestrus than those at proestrus and estrus $(\mathrm{P}<0.01)$.

\section{mRNA expression of Crlr and Ramps in cycling rats}

The Crlr, Ramp1, Ramp2, and Ramp3 mRNA levels estimated by real-time RT-PCR are shown in Figure 2. The Crlr mRNA level was significantly lower at estrus than that at proestrus $(\mathrm{P}<0.05)$ while the Ramp2 level was lower at metestrus than all the other stages $(\mathrm{P}<0.05)$. No changes were observed for Ramp1 and Ramp3 mRNA levels.

\section{Gel filtration chromatographic analysis of the uterus}

At both the estrous $(n=5)$ and diestrous stages $(n=5)$, two immunoreactive IMD peaks were observed on the gel filtration chromatograms at fractions 15 and 25. At estrus, there was a higher peak of IMD than the IMD precursor while at diestrus, a predominant peak of IMD precursor and a smaller peak of IMD were seen (Figure 3). The IMD peak was much higher at estrus 

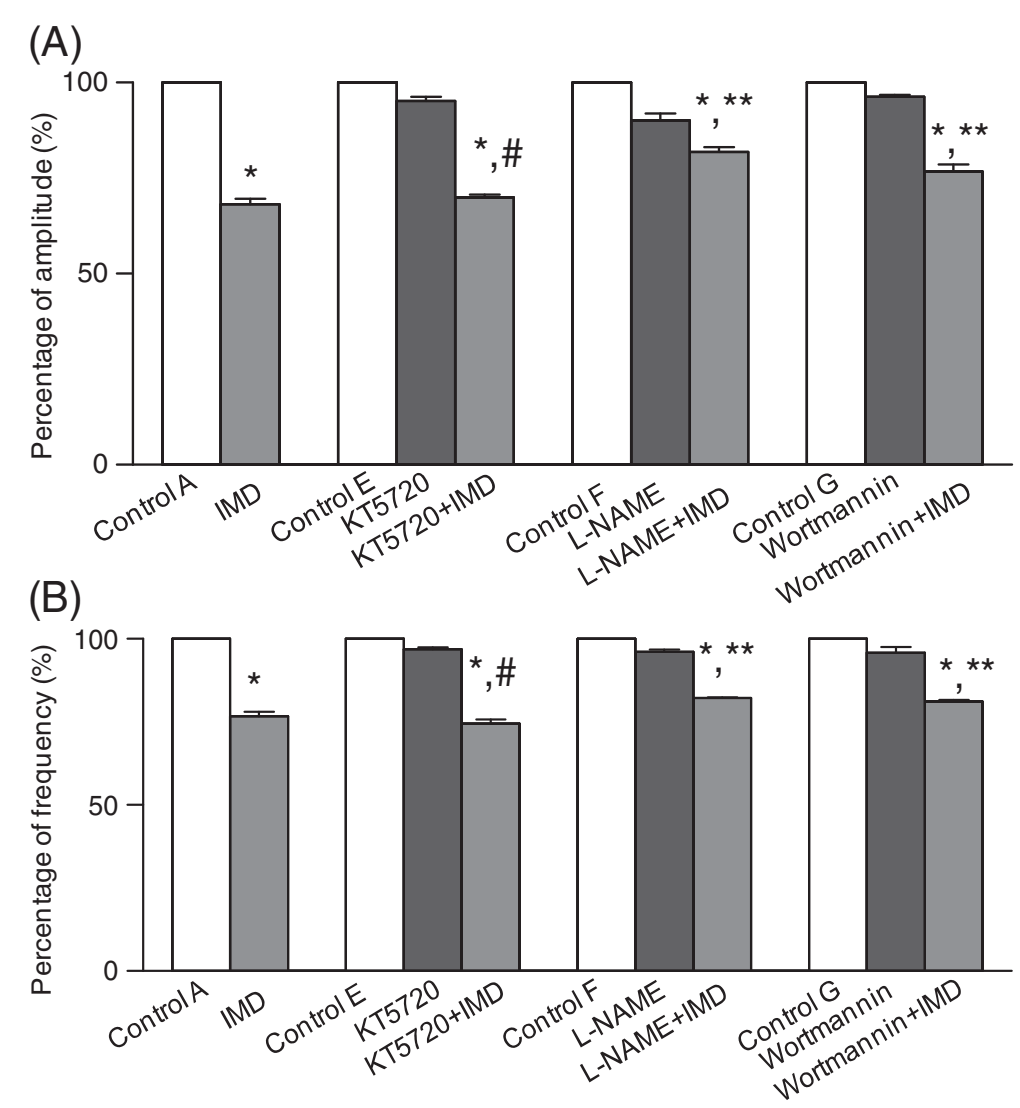

Figure 7 The effects of inhibitors in signaling pathways on the suppression of uterine contraction by IMD. Decreased amplitude (A) and frequency (B) were observed after the IMD treatment. Both L-NAME and Wortmannin partially blocked IMD actions (A and B). KT5720 had no effects on uterine contraction mediated by IMD. ${ }^{*} \mathrm{P}<0.01$ vs control or inhibitor alone, ${ }^{* * P}<0.01$ vs IMD, $\# P<0.01$ vs L-NAME+IMD or Wortmannin+IMD.

than at diestrus. Since the authentic $\mathrm{IMD}_{1-53}, \mathrm{IMD}_{1-47}$ and $\mathrm{IMD}_{8-47}$ were eluted at fractions 22,25 and 27 respectively, the low molecular peak in the sample corresponded to $\mathrm{IMD}_{1-47}$.

\section{Immunohistochemical study of IMD}

Positive immunostaining was observed in the rat uterus at both estrus and diestrus in the luminal and glandular epithelial cells with similar intensities at the two stages (Figure 4).

\section{Effects of IMD and its receptor antagonists and inhibitors on uterine contraction}

Representative tracings of the rat uteri treated with IMD, receptor antagonists and signaling pathways inhibitors are shown in Figure 5. IMD inhibited uterine contraction in both frequency and amplitude (Figure 5A). Treatment of rat uteri with IMD significantly lowered the amplitude and frequency of contraction by 33.67 $\pm 0.78 \%$ and $20.34 \pm 1.33 \%$ respectively $(P<0.05$, Figure $6 \mathrm{~A}$ and $\mathrm{B}$ ) but had no effects on the basal tone (results not shown). Both hADM ${ }_{22-52}$ and hCGRP ${ }_{8-37}$ partially blocked the action of IMD on the amplitude (Figure 5B and $\mathrm{C}$ ) and the amplitude decreased only by $16.42 \pm$ $2.01 \%$ and $20.27 \pm 1.26 \%$ respectively (vs $33.67 \pm 0.78 \%$ for IMD alone, $\mathrm{P}<0.05$, Figure $6 \mathrm{~A})$. Only $\mathrm{hADM}_{22-52}$ but not the hCGRP 8 -37 partially blocked the IMD action on frequency and the decrease was only $12.42 \pm 1.01 \%$ (vs $20.34 \pm 1.33 \%$ for IMD alone, $\mathrm{P}<0.05$, Figure $6 \mathrm{~B}$ ). hIMD $_{17-47}$ completely blocked the relaxation effect of IMD on both amplitude and frequency (Figures 5D, 6A and B). The use of KT5720 did not alter the responses of the contraction amplitude and frequency to IMD (Figure 5E) while the effects of IMD were partially inhibited by both L-NAME and Wortmannin (Figure $5 \mathrm{~F}$ and G). In the presence of L-NAME and Wortmannin IMD decreased the amplitude by $19.13 \pm 1.27$ and $23.28 \pm 1.80 \%$ (vs 33.67 $\pm 0.78 \%$ for IMD alone, $\mathrm{P}<0.05$, Figure $7 \mathrm{~A})$ and the frequency by $15.85 \pm 2.2$ and $16.92 \pm 5.2 \%$ (vs $20.34 \pm 1.33 \%$ for IMD alone, $\mathrm{P}<0.05$, Figure $7 \mathrm{~B}$ ).

\section{Discussion}

We have here demonstrated the changes of uterine IMD levels in the estrous cycle and the effect of IMD on rat 
uterine contraction for a better understanding of the possible roles of IMD in the female reproductive tract. IMD decreased uterine contraction, in line with the findings for ADM $[25,26]$. Our study also confirmed that Crlr, Ramp1, Ramp2, and Ramp3 are expressed in the uterus [26], suggesting that both ADM and CGRP receptors are present in this organ. Uterine IMD pep tide level was higher at diestrus than at estrus with no change in gene expression. However, according to the gel filtration chromatogram, much of the IMD immunoreactivity at diestrus was due to the precursor and the amount of $\mathrm{IMD}_{1-47}$ was actually lower than at estrus. The relative abundance of the precursor IMD at diestrus may be explained by the decreased processing of the precursor protein or the increased secretion of the active IMD. As the Imd mRNA level at diestrus was not higher than at estrus, an increase in synthesis with a concomitant increase in release appears to be less likely. Rather, the smaller IMD peak at diestrus may be due to the decrease in its formation from the precursor. Our results suggest there is a difference in the proteolytic processing of the IMD precursor molecule. Regardless of the cause, an increase in the $\mathrm{IMD}_{1-47}$ at estrus would mean a greater IMD action compared with diestrus. This may be related to uterine contraction (the present study) or angiogenesis as intermedin is an angiogenic growth factor [40]. The significance of an increase of Imd mRNA at proestrus remains unclear.

We were able to demonstrate for the first time that IMD inhibited spontaneous uterine contraction in rat by reducing the contraction amplitude and frequency by 33.67 and $20.34 \%$ respectively. The magnitude of inhibition was similar to that reported for ADM on galanininduced contraction [25], where the entire uterus was used, and was less than that reported for ADM on basal contraction [26], where uterine strips were used. This inhibitory effect of IMD was reversed by both ADM and CGRP receptor antagonists, as was previously reported for ADM [26]. However, there is one minor difference between our study and the study of Yanagita et al. [26] in the way to achieve synchronization of the physiological state in the female rat. We injected the immature female SD rats with PMSG while Yanagita et al. injected the mature female SD rats with estradiol, but both methods synchronized the rats to the estrous stage. This inhibitory effect was reported at estrus when the $\mathrm{IMD}_{1-47}$ level was higher and may synergize with the inhibitory effect of ADM.

We have not studied the IMD effects in induced uterine contraction. In galanin-induced contraction in the rat, ADM inhibited contraction via CGRP receptor only [25]. CGRP inhibited galanin-induced [25] and substance $\mathrm{P}$-induced contraction in the rat [41], and $\mathrm{KCl}$-induced contraction in the human [42] and these effects were mediated by the CGRP receptor. In some of the CGRP actions on the uterus, the NO pathway was involved [43], but not in others [44].

In this study, both hADM ${ }_{22-52}$ and hCGRP $_{8-37}$ partially blocked the inhibitory effect of IMD on rat uterine contraction while hIMD $_{17-47}$ exhibited complete inhibition. These results suggest that IMD modulate uterine contraction mostly by specific IMD receptor and partially by CGRP and ADM receptors. In addition, our study has shown that both NO and PI3K pathways are involved in IMD mediated uterine contraction. The use of L-NAME (NO blocker) and Wortmannin (PI3K blocker) significantly reduced the decreases in amplitude and frequency induced by IMD but KT5720 (PKA blocker) did not alter the IMD action. The L-NAME inhibition may be mediated by PKG, which is activated by cGMP in the NO pathway leading to the dephosphorylation of myosin light chain to relax the uterine smooth muscle [43]. Another NO-mediated IMD effect on contraction has been reported in the rat papillary muscle [45]. The PI3K pathway for inhibiting smooth muscle contraction has also been reported in gastrointestinal smooth muscles [46] and an involvement of PI3K pathway for an IMD effect can be found in endoplasmic reticulum stress [21]. The cAMP-PKA system is not involved as the use of PKA blocker had no effect on IMD actions although the elevation of cAMP production was one of the characteristic features in the early study of IMD [2].

\section{Conclusions}

In conclusion, IMD and the gene expression of its receptor components are differentially expressed in the uterus across the estrous cycle. IMD inhibits uterine contraction by decreasing the amplitude and frequency. This inhibitory effect at estrus may synergize with the inhibitory effect of $\mathrm{ADM}$ when the $\mathrm{IMD}_{1-47}$ level was higher.

\section{Competing interests}

The authors declare that they have no competing interests.

\section{Authors' contributions}

CWW worked on the collection of tissues, real time PCR, EIA, gel filtration chromatography, immunohistochemistry, contractility study by organ bath technique, performed the statistical analysis and drafted the manuscript. FT and WSO coordinated the project. FT and WSO are respectively the principal and co-investigators of the research and holders of the grant. Both FT and WSO assisted in the manuscript revision. All authors read and approved the final manuscript.

\section{Acknowledgements}

This study was generously supported by a research grant awarded to Fai Tang and Wai Sum O by the Elaine GCF Tso Memorial Fund Committee of Management, the University of Hong Kong. We would like to thank Ms May Cheung and Molly Wong for their technical assistance.

\section{Author details}

${ }^{1}$ Departments of Physiology, Li Ka Shing Faculty of Medicine, The University of Hong Kong, Pokfulam, Hong Kong SAR, China. '2Department of Anatomy, 
Li Ka Shing Faculty of Medicine, The University of Hong Kong, Pokfulam, Hong Kong SAR, China. ${ }^{3}$ Center of Growth, Reproduction and Development, Li Ka Shing Faculty of Medicine, The University of Hong Kong, Pokfulam, Hong Kong SAR, China. ${ }^{4}$ Center of Heart, Brain, Hormone and Healthy Aging, Li Ka Shing Faculty of Medicine, The University of Hong Kong, Pokfulam, Hong Kong SAR, China.

Received: 7 December 2012 Accepted: 19 February 2013 Published: 25 February 2013

\section{References}

1. Chang CL, Roh J, Hsu SYT: Intermedin, a novel calcitonin family peptide that exists in teleosts as well as in mammals: a comparison with other calcitonin/ intermedin family peptides in vertebrates. Peptides 2004, 25:1633-1642.

2. Roh J, Chang CL, Bhalla A, Klein C, Hsu SY: Intermedin is a calcitonin/CGRP family peptide acting through the CRLR/RAMP receptor complexes. J Biol Chem 2004, 279:7264-7274.

3. Takei Y, Hyodo S, Katafuchi TN, Minamino N: Novel fish-derived adrenomedullin in mammals: structure and possible function. Peptides 2004, 25:1643--1656.

4. Taylor MM, Samson WK: Stress hormone secretion is altered by central administration of intermedin/adrenomedullin-2. Brain Res 2005, 1045:199-205.

5. Taylor MM, Bagley SL, Samson WK: Intermedin/adrenomedullin-2 acts within the central nervous system to elevate blood pressure and inhibit food and water intake. Am J Physiol 2005, 288:R919-R927.

6. Takahashi K, Kikuchi K, Maruyama Y, Urabe T, Nakajima KH, Sasano H Immunocytochemical localization of adrenomedullin-2/intermedin-like Immunoreactivity in human hypothalamus, heart and kidney. Peptides 2006, 27:1383-1389

7. Bell D, McDermott BJ: Intermedin (adrenomedullin-2): a novel counter-regulatory peptide in the cardiovascular and renal systems. Br J Pharmacol 2008, 153:S247-S262.

8. Kitamura K, Kangawa K, Kawamoto M, Ichiki Y, Nakamura SH, Matsuo H: Adrenomedullin: a novel hypotensive peptide from human phaeochromocytoma. Biochem Biophys Res Commun 1993, 192:553-560.

9. Eto T: A review of the biological properties and clinical implications of adrenomedullin and proadrenomedullin N-terminal 20 peptide (PAMP), hypotensive and vasodilating peptides. Peptides 2001, 22:1693-1711.

10. Reidelberger RD, Kelsey L, Heimann D: Effects of amylin-related peptides on food intake, meal patterns, and gastric emptying in rats. Am J Physiol Regul Integr Comp Physiol 2002, 282:R1395-R1404.

11. Dunning BE, Taborsky GJ Jr: Calcitonin gene-related peptide: a potent and selective stimulator of gastrointestinal somatostatin secretion. Endocrinology 1987, 120:1774-1781.

12. Rossowski WJ, Jiang NY, Coy DH: Adrenomedullin, amylin, calcitonin gene related peptide and their fragments are potent inhibitors of gastric acid secretion in rats. Eur J Pharmacol 1997, 336:51-63.

13. Meeran K, O'Shea D, Upton PD, Small CJ, Ghatei MA, Byfield PH, Bloom SR: Circulating adrenomedullin does not regulate systemic blood pressure but increases plasma prolactin after intravenous infusion in humans: a pharmacokinetic study. J Clin Endocrinol Metab 1997, 82:95-100.

14. Troughton RW, Lewis LK, Yandle TG, Richards AM, Nicholls MG MG: Hemodynamic, hormone, and urinary effects of adrenomedullin infusion in essential hypertension. Hypertension 2000, 36:588-593.

15. Chauhan M, Yallampalli U, Dong YL, Hankins GDV, Yallampalli C: Expression of adrenomedullin 2(ADM2)/intermedin (IMD) in human placenta: role in trophoblast invasion and migration. Biol Reprod 2009, 81:777-783.

16. Song JQ, Teng X, Cai Y, Tang CS, Qi YF: Activation of Akt/GSK-3beta signaling pathway is involved in intermedin (1-53) protection against myocardial apoptosis induced by ischemia/reperfusion. Apoptosis 2009, 14:1299-1307.

17. Zeng Q, Yuan Y, Wang X, Wu HM, Fan L, Qi YF, Tang CS, Cai Y, Pan CS. Upregulated expression of intermedin and its receptor in the myocardium and aorta in spontaneously hypertensive rats. Peptides 2009, 30:391-399.

18. Albertin G, Sorato E, Oselladore B, Mascarin A, Tortorella C, Guidolin D: Involvement of vascular endothelial growth factor signaling in CLR/ RAMP1 and CLR/RAMP2-mediated pro-angiogenic effect of intermedin on human vascular endothelial cells. Int J Mol Med 2010, 26:289-294.

19. Chauhan M, Balakrishnan M, Yallampalli U, Endsley J, Hankins GDV, Theiler R, Yallampalli C: Adrenomedullin 2(ADM2)/ Intermedin (IMD) regulates HLA-G in human trophoblasts. Biol Reprod 2011, 85:1232-1239.
20. Chauhan M, Elkins R, Balakrishnan M, Yallampalli C: Potential role of intemedin/adrenomedullin 2 in early embryonic development in rats. Regul Pept 2011, 170:65-71.

21. Teng X, Song JQ, Zhang GG, Cai Y, Yuan F, Du J, Tang CS, Qi YF: Inhibition of endoplasmic reticulum stress by intermedin1-53 protects against myocardial injury through a PI3 kinase-Akt signaling pathway. J Mol Med 2011, 89:1195-1205.

22. Chang $\mathrm{CL}$, Wang HS, Soong YK, Huang SY, Pai SY, Hsu SY: Regulation of oocyte and cumulus cell interactions by intermedin/adrenomedullin 2 . J Biol Chem 2011, 286:43193-43203.

23. Cameron VA, Autelitano DJ, Evans JJ, Ellmers LJ, Espiner EA, Nicholls MG, Richards AM: Adrenomedullin expression in rat uterus is correlated with plasma estadiol. Am J Phyisol Endorinol Metab 2002, 282:E139-E146.

24. Watanabe H, Takahashi E, Kobayashi M, Goto M, Krust A, Chambon P, Iguchi $\mathrm{T}$ : The estrogen-responsive adrenomedullin and receptor-modifying protein 3 gene identified by DNA microarray analysis are directly regulated by estrogen receptor. J Mol Endocrinol 2006, 36:81-89.

25. Upton PD, Austin C, Taylor GM, Nandha KA, Clark AJ, Ghatei MA, Bloom SR, Smith DM: Expression of adrenomedullin(ADM) and its binding sites in the rat uterus: increased number of binding sites and ADM messenger ribonucleic acid in 20-day pregnant rats compared with nonpregnant rats. Endocrinology 1997, 138:2508-2514

26. Yanagita $T$, Yamamoto $R$, Sugano $T$, Kobayashi $H$, Uezono $Y$, Yokoo $H_{\text {, }}$ Shiraishi S, Minami SI, Wada A: Adrenomedullin inhibits spontaneous and bradykinin-induced but not oxytocin- or prostaglandin $\mathrm{F}_{2 \mathrm{a}}$-induced periodic contraction of rat uterus. Br J Pharmacol 2000, 130:1727-1730.

27. Michishita M, Inegishi T, Abe K, Kangawa K, Kojima M, Ibuki Y: Expression of adrenomedullin in the endometrium of the human uterus. Obstet Gynecol 1999, 93:66-70.

28. Hwang SS, Autelitano DJ, Wong YD, Leung PH, Tang F: Co-expression of adrenomedullin and adrenomedullin receptors in rat epididymis: distinct physiological actions on anion transport. Bio Reprod 2003, 68:2005-2012.

29. Li YY, Hwang SS OWS, Tang F: Adrenomedullin peptide: gene expression of adrenomedullin, its receptor and receptor activity modifying proteins, and receptor binding in rat testis-actions on testosterone secretion. Biol Reprod 2006, 75:183-188.

30. Li YY OWS, Tang F: Effect of aging on the expression of adrenomedullin and its receptor component proteins in the male reproductive system of the rat. J Gerontol Biol Sci 2007, 62:1346-1351.

31. Chan YF, WS O, Tang F: Adrenomedullin in the rat testis I. its production, actions on testosterone secretion, regulation by human chorionic gonadotropin, and its interaction with endothelin-1 in the Leydig cell. Bio Reprod 2008, 78:773-779

32. Chan YF, Tang F, WS O: Adrenomedullin in the rat testis II: its production, actions on inhibin secretion, regulation by follicle stimulating hormone, and its interaction with endothelin-1 in the Sertoli cells. Bio Reprod 2008 78:780-785.

33. Li YY, Li L, Hwang SS, Tang F, WS O: Coexpression of adrenomedullin and its receptors in the reproductive systems of the rat: effects on steroid secretion in rat ovary. Biol Reprod 2008, 79:200-208.

34. Li L, Tang F, WS O: Coexpression of adrenomedullin and its receptor component proteins in the reproductive system of the rat during gestation. Reprod Biol Endocrinol 2010, 8:130-141.

35. Liao SB, Ho JC, Tang F, WS O: Adrenomedullin increases ciliary beat frequency and decreases muscular contraction in the rat oviduct. Reproduction 2011, 141:367-372.

36. Li L, WS O, Tang F: Pre-implantation antagonism of adrenomedullin action resulted in a reduced litter size and compromised fetoplacental development. Theriogenology 2012, 77:1846-1853.

37. Liao SB, Kong HM, Tang F, WS O: Possible functions of adrenomedullin from the seminal fluid in the female reproductive tracts of the rat. Syst Biol Reprod Med 2012, 58:306-312.

38. Liao SB OWS, Tang F: Adrenomedullin inhibits norepinephrine-induced contraction of the rat seminal vesicle. Urology 2012, 8:224e1-224e5.

39. Livak KJ, Schmittgen TD: Analysis of relative gene expression data using real-time quantitative $P C R$ and the 2- $\triangle \Delta C T$ method. Methods 2001, 25:402-408

40. Smith RS Jr, Gao L, Bledsoe G, Chao L, Chao J: Intermedin is a new angiogenic growth factor. Am J Physiol Heart Circ Physiol 2009, 297:H1040-H1047.

41. Shew RL, Papka RE, McNeill DL: Substance $P$ and calcitonin gene-related peptide immunoreactivity in nerves of the rat uterus: localization, colocalization and effects on uterine contractility. Peptides 1991, 12:593-600. 
42. Chan KK, Robinson G, Broughton PF: Differential sensitivity of human nonpregnant and pregnant myometrium to calcitonin gene-related peptide. J Soc Gynecol Investig 1997, 4:15-21.

43. Shew RL, Papka RE, McNeill DL, Yee JA: NADPH-diaphorase-positive nerves and the role of nitric oxide in CGRP relaxation of uterine contraction. Peptides 1993, 14:637-641.

44. Naghashpour M, Dahl G: Relaxation of myometrium by calcitonin gene-related peptide is independent of nitric oxide synthase activity in mouse uterus. Biol Reprod 2000, 63:1421-1427.

45. Pires AL, Pinho M, Sena CM, Seica R, Leite-Moreira AF: Intermedin elicits a negative inotropic effect in rat papillary muscles mediated by endothelialderived nitric oxide. Am J Physiol Heart Circ Physiol 2012, 302:H1131-H1137.

46. Van Geldre LA, Lefebvre RA: Interaction of NO and VIP in gastrointestinal smooth muscle relaxation. Curr Pharm Des 2004, 10:2483-2497.

doi:10.1186/1477-7827-11-13

Cite this article as: Wong et al:: Intermedin in rat uterus: changes in gene expression and peptide levels across the estrous cycle and its effects on uterine contraction. Reproductive Biology and Endocrinology 2013 11:13.

\section{Submit your next manuscript to BioMed Central and take full advantage of:}

- Convenient online submission

- Thorough peer review

- No space constraints or color figure charges

- Immediate publication on acceptance

- Inclusion in PubMed, CAS, Scopus and Google Scholar

- Research which is freely available for redistribution 